\title{
SEJARAH DAN IMPLIKASI POLITIS PENERIMAAN ISLAM DI SINJAI
}

Oleh: Muh. Anis ${ }^{1}$

\begin{abstract}
$* * *$
Abstrak

Sejarah penerimaan Islam di Sulawesi Selatan berimplikasi pada perubahan tatanan sosial politik hubungan antar kerajaan yang eksis saat itu. Penerimaan Islam secara top down; dari penguasa ke rakyat umum, menyebabkan perubahan tatanan pelaksanaan kekuasaan;pemerintahan. Tak terkecuali di Sinjai, implikasi penerimaan Islam penguasa dan rakyat umum, menyebabkan kultur baru dalam tatanan sosial politik, yakni kultur islami dengan berbagai status sosial lembaga atau individu. Status tersebut memiliki fungsi di tengah-tengah masyarakat, yang sifatnya dapat disebut sebagai pelayanan spiritual.
\end{abstract}

Kata Kunci : Sejarah, Implikasi Politis dan penerimaan Islam di Sinjai

\section{PENDAHAULUAN}

O injai merupakan salah satu daerah pemerintahan tingkat kabupaten di - Provinsi Sulawesi Selatan. Daerah ini terbentuk dari proses sejarah yang panjang. Sinjai dibangun dari sejumlah kerajaan yang memiliki kekuasaan dengan karakteristik masing-masing. Kerajaan-kerajaan tersebut terbagi atas dua kelompok, yang dikenal dengan nama federasi Tellu Limpoe dan Pitu Limpoe. Wilayah kekuasaan Tellu Limpoe terletak di sekitar pesisir pantai. Federasi Tellu Limpoe adalah gabungan tiga kerajaan yaitu Tondong, Bulo-bulo, dan Lamatti. Sedangkan, wilayah federasi Pitu Limpoe atau Pitu ri Wawo Bulu (Tujuh di atas Gunung) yang berada di dataran tinggi adalah gabungan Kerajaan Turungeng, Manimpahoi, Terasa, Pao, Manipi, Suka, dan Bala Suka. ${ }^{2}$

Pada awal abad 17 M., agama Islam massif menjadi perhatian para penguasa dan masyarakat umum di Sulawesi Selatan. Pengenalan dan penerimaan

\footnotetext{
${ }^{1}$ Dosen STAI Muhammadiyah Sinjai

${ }^{2}$ Moh. Yahya Mustafa dan A. Wanua Tungke, Sinjai 10 Tahun dalam Memori (Cet. I; Makassar: Pustaka refleksi, 2002), h. 3.
} 


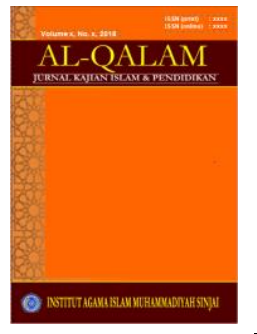

AL-QALAM

Jurnal Kajian Islam \& Pendidikan

Volume 06 No 012014

ISSN (print) : 1858-4152

ISSN (online) : -

Homepage : http://journal.iaimsinjai.ac.id/index.php/al-qalam

masyarakat terhadap Islam menjadi paradigma baru untuk eksistensi mereka. Khusus bagi kerajaan Gowa Tallo, Islam menjadi spirit dalam melanjutkan hegemoni mereka di Sulawesi Selatan. Dimulai pada penerimaan dan ditetapkannya Islam sebagai agama resmi Kerajaan Gowa Tallo. Raja Gowa pada waktu itu, I Mangarangi Daeng Manrabia yang bergelar Sultan Alauddin mengeluarkan dekrit pada tahun $1607 .{ }^{3}$ Dekrit yang berisi titah raja menjadikan Islam sebagai agama resmi kerajaan, dan memaklumkan Islam sebagai agama masyarakat.

Dekrit itupun ditindaklanjuti dengan seruan kepada Islam di kerajaankerajaan tetangga. Seruan masuk Islam kepada kerajaan-kerajaan kecil diterima dengan damai. Sementara seruan masuk Islam diterima secara damai ditolak dengan keras oleh kerajaan Bugis yang kuat, seperti Kerajaan Sidenreng, Soppeng, Wajo, dan Bone. Penolakan keras tersebut direspon oleh Kerajaan Gowa Tallo dengan ekspedisi perang-yang diistilahkan musu selleng- sebanyak empat kali yang dimulai pada tahun 1608 sampai takluknya Kerajaan Bone tahun 1611. ${ }^{4}$

Penaklukan Kerajaan Gowa Tallo dengan jargon musu selleng patut dicurigai. Benarkah? motivasinya atas nama Islam, atau ada alasan lain?, yang jelas penerimaan Islam di kerajaan-kerajaan Bugis seperti yang disebutkan sebelumnya, justru menampakkan realitas, Islam sangat berkembang dengan pesat di daerah itu. walaupun butuh waktu kurang lebih dua abad kemudian berdiri pondok pesantren As'adiyah di Wajo yang pertama di Sulawesi Selatan. Tetapi tentu tidak dapat juga dihindari adanya nuansa politis penaklukan kerajaan Gowa Tallo tersebut.

\section{PEMBAHASAN}

\section{A. Konstalasi Politis Penerimaan Islam di Sinjai}

Sebagaimana dikutip sebelumnya, seruan Kerajaan Gowa Tallo agar Islam diterima secara damai oleh kerajaan-kerajaan kecil. Kerajaan-kerajaan di Sinjai masuk dalam kategori tersebut. Ada beberapa alasan yang dapat dikemukakan

${ }^{3}$ Mustari Mustafa, Agama dan Bayang-bayang Etis Syaik Yusuf al-Makassari (Cet. I; Makassar: 2011), h. 16. Dekrit ini diumumkan pada tanggal 9 Nopember 1607/19 Rajab 1016, pada pelaksanaan shalat Jum'at pertama kalinya di mesjid Mangallekana Tallo. Lihat, J. Noorduyn, De Islamisering van Makassar diterjemahkan oleh S. Gunawan dengan judul Islamisasi Makassar (Cet. I; Jakarta: Bhratara, 1972), h. 35. Dan lihat, Abd. Razak Daeng Patunru, Sejarah Gowa (Cet. I; Ujung Pandang: Yayasan Kebudayaan Sulawesi Selatan, 1967), h. 20.

${ }^{4}$ Mattulda, Sejarah Masyarakat dan Kebudayaan Sulawesi Selatan (Cet. I; Ujung Pandang: Lembaga Penerbitan Universitas Hasanuddin, 1998), h. 152. 


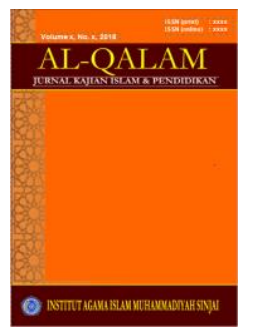

terkait penerimaan Islam oleh kerajaan-kerajaan di Sinjai secara damai, yakni: Pertama, usaha Kerajaan Gowa mempeluas wilayah kekuasaan, sebelum Islam diterima. Walaupun bersifat agresif dan ekspansif, tetapi lebih memberikan kelonggaran otonomi atas wilayah-wilayah yang dikuasai dengan pengawasan saja. ${ }^{5}$ Kedua, kontekstualisasi Perjanjian Topekkong. ${ }^{6}$ Esensi perjanjian ini adalah komunike persekutuan antara Kerajaan Tellu Limpoe dengan Kerajaan Gowa, dan membangun inklusifitas (keterbukaan) pada usaha-usaha perbaikan untuk kemajuan bersama. Ketiga, konsekwensi Perjanjian Caleppa. ${ }^{7}$

Merujuk pada ketiga argumentasi tersebut, dapat dimengerti bahwa penerimaan Islam di Sinjai secara damai dimotivasi kultur politis yang sudah berkembang sampai diterimanya Islam. Kultur politis yang terbangun itu telah melalui beberapa dinamika perkembangan sosial politik antar kerajaan-kerajaan di Sulawesi Selatan. Dinamika itu sendiri dapat dimaknai sebagai "ujian" kejujuran, kerjasama saling menguntungkan, dan perdamaian antar kerajaan.

Selain pengaruh kultur politik Kerajaan Gowa penting dicermati bahwa kerajaan-kerajaan di Sinjai, khususnya federasi Tellu Limpoe, pernah berafiliasi kepada Kerajaan Bone. ${ }^{8}$ Peristiwa afiliasi itu terjadi saat terjadi konflik perebutan hegemoni kekuasaan antara Kerajaan Gowa dan Kerajaan Bone yang dimulai pada tahun 1562 sampai terjadinya perjanjian Caleppa $1565 .^{9}$

Afiliasi kerajaan Tellu Limpoe kepada Kerajaan Bone, menyebabkan adanya pengaruh kultural tersendiri. Menurut Mattulada, bahwa dalam usaha perluasan wilayah kekuasaan Kerajaan Bone bersifat ekspansif, dengan memberi tekanan pada penguasaan langsung atas negeri-negeri yang ditaklukkan melalui perang atau datang bergabung secara sukarela (Tellu Limpoe) sebagai palili (taklukan secara damai). Penguasaan secara langsung itu dilakukan melalui pengangkatan pejabat-pejabat dari Kerajaan Bone dan menerapkan konsep

${ }^{5}$ Ibid., h. 94.

${ }^{6}$ Moh. Yahya Mustafa dan A. Wanua Tungke, Sinjai 10 Tahun dalam Memori (Cet. I; Makassar: Pustaka Refleksi, 2002), h. 6.

${ }^{7}$ Ahmad Massiara Daeng Rapi, Menyingkap Tabir Sejarah Budaya di Sulawesi Selatan (Cet. I; Jakarta: Lembaga Penelitian dan Pelestarian Sejarah dan Budaya Sulawesi Selatan, 1988), h. 48 .

${ }^{8}$ Abdul Razak Daeng Patunru dkk, Sejarah Bone (Cet. I; Ujung Pandang: Yayasan Kebudayaan Sulawesi Selatan, 1989), h. 44-46.

${ }^{9}$ Ibid., h. 51. 


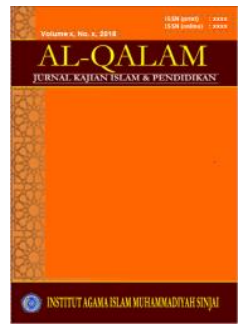

pangngaderreng (adat) seperti yang diberlakukan di Bone. ${ }^{10} \mathrm{Jadi}$, afiliasi kerajaan Tellu Limpoe kepada Kerajaan Bone, menyebabkan masyarakat Sinjai dipengaruhi oleh kultur pangngaderreng kerajaan Bone.

\section{B. Penerapan Syariat Islam di Sinjai}

Berdasar uraian beberapa uraian sebelumnya, pada aspek sistem politik pemerintahan, kerajaan-kerajaan yang ada di Sinjai, mendapat pengaruh dari Kerajaan Gowa. Sedangkan dalam aspek sistem sosial, mendapat pengaruh dari Kerajaan Bone. Situasi dan kondisi itu, menjadi prakondisi kerajaan-kerajaan di Sinjai yang mempermudah penerapan syariat Islam (sara'), di wilayah-wilayah pemerintahannya.

Keberhasilan Abdul Makmur Khatib Tunggal menjadikan Islam diterima secara resmi di Kerajaan Gowa pada tahun $1605,{ }^{11}$ kemudian menetap dalam rangka mengajarkan dan menyebarkan Islam berdasarkan syariat Islam. ${ }^{12} \mathrm{Hal}$ ini menjadi dasar penerapan syariat Islam melalui sistem pemerintahan. Kemudian, Abdul Makmur Khatib Tunggal datang ke Sinjai (atas permintaan Raja Bulo-bulo, La Pateddungi) dan tinggal selama kurang lebih tiga tahun (1607-1610). ${ }^{13}$

Kehadiran Abdul Makmur Khatib Tunggal tersebut, dapat diasumsikan semakin memantapkan penerapan syariat Islam melalui sistem pemerintahan kerajaan-kerajaan Sinjai. Di sisi lain, eksistensi Abdul Jawad Khatib Bungsu di Tiro, yang diperkuat dengan masuknya Islam La Unru Daeng Biasa (Raja Tiro) pada tahun 1604. Mereka kemudian bahu membahu menyebarkan Islam, di daerah Timur Bulukumba sampai di daerah Utara, pesisir Sinjai. ${ }^{14}$ Pada dasarnya mempersiapkan mental masyarakat menerima syariat Islam, hal itu disebabkan karena Abdul Jawad Khatib Bungsu, menyebarkan Islam menempuh cara edukatif dengan pendekatan tasawuf. ${ }^{15}$

${ }^{10}$ Mattulda, op. cit., h. 94.

${ }^{11} \mathrm{~J}$. Noorduyn, De Islamisering van Makassar, diterjemahkan oleh S. Gunawan, dengan judul, Islamisasi Makassar (Cet. I; Jakarta: Bharata, 1972), h. 29-30.

${ }^{12}$ Mattulada, op. cit., h. 154.

${ }^{13}$ Basrah Gising, Attoriolongnge ri Bulo-bulo, Tondong, Lamatti-Sejarah Kerajaan Bulobulo, Tondong, dan Lamatti (Suatu Bentuk Manifestasi "Sinjai Bersatu”) (Cet. I; Makassar: Era Media, 2002), h.193.

${ }^{14}$ Salahuddin, Skripsi "Kerajaan Bulo-bulo dalam Persekutuan Tellu Limpoe” (IKIP Ujung Pandang: Fakultas Ilmu Sosial, 1997), h. 34.

${ }^{15}$ Mattulada, lo. cit. 


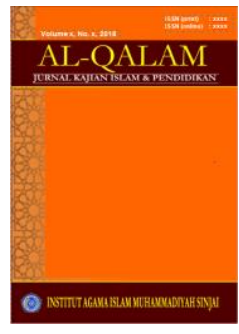

AL-QALAM

Jurnal Kajian Islam \& Pendidikan

Volume 06 No 012014

ISSN (print) : 1858-4152

ISSN (online) : -

Homepage : http://journal.iaimsinjai.ac.id/index.php/al-qalam

Mengenai kesuksesan Abdul Makmur Khatib Tunggal dan Abdul Jawad Khatib Bungsu menyebarkan Islam, yang disokong oleh raja dengan kekuasaan yang dimiliki. Realitas itu dapat dipahami dalam tulisan Soejono Soekanto, bahwa:

Kekuasaan yang dapat dijumpai pada interaksi sosial antara manusia maupun kelompok mempunyai beberapa unsur pokok, yakni: Pertama, rasa takut. Perasaan takut seseorang pada penguasa menimbulkan suatu kepatuhan terhadap segala kemauan dan tindakan orang yang ditakuti. Kedua, rasa cinta. Rasa cinta menyebabkan orang lain bertindak sesuai dengan kehendak orang yang berkuasa, untuk menyenangkan semua pihak. Ketiga, kepercayaan. Kepercayaan dapat timbul sebagai hasil hubungan langsung antara dua orang atau lebih yang bersifat asosiatif. Keempat, pemujaan. Dalam sistem pemujaan, seseorang atau sekelompok orang yang memegang kekuasaan, mempunyai dasar pemujaan dari orang lain. Akibatnya, segala tindakan penguasa dibenarkan atau setidak-tidaknya dianggap benar. ${ }^{16}$

Penerapan sara' secara praktis dalam kehidupan sosial politik di Sinjai dapat diketahui melalui tulisan Basrah Gising. Tulisan itu memuat pernyataan La Pateddungi, bahwa di daerah kekuasaannya pemberlakuan sara' dipegang oleh Dato'(Abdul Makmur Khatib Tunggal atau Dato' ri Bandang), sementara kekuasaanku dalam Pangngaderreng dipegang oleh Sullewatang (Pejabat Kerajaan). Ada enam wewenang dalam pelaksanaan sara' yakni: (1). Kerbau harus disembelih oleh Dato', (2). Dato' saja yang boleh menikahkan, (3). Memandikan mayat dan membacakan talkin hanya Dato', (4). Yang berhak membagikan zakat hanya dato', (5). Penerimaan zakat hanya kepada Dato', (6). Semua zakat harus terkumpul kepada Dato' untuk kemudian dibagikan kepada yang berhak. ${ }^{17}$

Berbicara mengenai wewenang Dato' tersebut, secara eksplisit menunjukkan adanya pembagian kekuasaan terhadap pelaksanaan pemerintahan. Wewenang dalam pembagian kekuasaan itu sekaligus menjelaskan urgensi (penting) kepemimpinan untuk melaksanakannya. Nampak kepemimpinan Dato', memenuhi tiga macam wewenang dalam pembagian kekuasaan, yaitu:

${ }^{16}$ Soejono Soekanto, Sosiologi-Suatu Pengantar (Cet. 38; Jakarta: Raja Grafindo Persada, 2005), h. 271-272.

${ }^{17}$ Basrah Gising, op. cit., h. 192. 


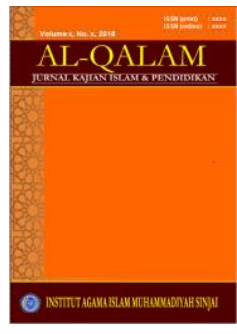

AL-QALAM

Jurnal Kajian Islam \& Pendidikan

Volume 06 No 012014

ISSN (print) : 1858-4152

ISSN (online) : -

Homepage : http://journal.iaimsinjai.ac.id/index.php/al-qalam

1. Wewenang Kharismatik. Wewenang ini didasarkan pada kemampuan khusus seseorang. Kemampuan ini melekat pada seseorang karena anugerah dari Tuhan yang Maha Kuasa.

2. Wewenang Tradisional. Merupakan wewenang yang dimiliki karena seseorang menjadi bagian dari kelompok. Kelompok ini, mempunyai kekuasaan dan wewenang yang telah melembaga dan bahkan menjiwai masyarakat.

3. Wewenang Rasional/legal. Wewenang yang bersandarkan pada sistem hukum yang berlaku dalam masyarakat. Sistem hukum ini dipahami sebagai kaidah-kaidah yang telah diakui dan ditaati oleh masyarakat, dan bahkan diperkuat oleh negara. ${ }^{18}$

Pada perkembangan selanjutnya, sara' melahirkan institusi sebagai sarana efektif dalam pembinaan dan pelayanan masyarakat. Institusi itu disebut Parewa Sara' (Pemangku Syariat), yang menangani tugas-tugas keagamaan secara formal. Pejabat tertinggi disebut khadi atau kali. Seorang kali bertugas sebagai penasehat penguasa dalam persoalan keagamaan. Untuk hal-hal tertentu, kali turun tangan langsung untuk memutuskan suatu persoalan, apakah menggunakan hukum sara' atau hukum ade'. Ia berhak mengontrol jabatan amele' (Amil;pengumpul Zakat), Imang (Imam) mesjid, Katte (Khatib), Bilala' (Bilal; petugas azan), dan Doja (Petugas kebersihan dan ketersediaan air wudhu). ${ }^{19}$

Pejabat-pejabat sara', terutama kali adalah orang terkemuka dalam kerajaan. Ia berasal dari kalangan anakarung (bangsawan) yang mempunyai pengetahuan mengenai Islam di atas rata-rata pengetahuan orang dalam istana. Status itu menyebabkan seorang kali mempunyai wibawa dan kharisma besar di samping raja. ${ }^{20}$ Eksistensi parewa sara' di Sinjai, dapat dibaca dalam tulisan J. Noorduyn sebagaimana dikutip Mattulada, bahwa:

Di Kerajaan Bulo-bulo pejabat sara' berjumlah empat puluh orang. Terdiri dari: dua orang kali (hakim tinggi), delapan orang khatib, delapan orang bilal, delapan orang mukim, dan tujuh orang wakil mukim. Kedelapan pejabat yang disebut mukim itu bertugas menghadiri shalat Jumat, mengatur

${ }^{18}$ Soejono Soekanto, op. cit., h. 280-283.

${ }^{19}$ Cristian Pelras, The Bugis diterjemahkan oleh Abdul Rahman Abu dkk. dengan judul Manusia Bugis (Cet. I; Jakarta: grafika Mardi Yuana, 2006), h. 213.

${ }^{20}$ Mattulada, Latoa-satu lukisan Analitis Terhadap Antropologi Politik Orang Bugis (Cet. I; Jogyakarta: Gadja Mada University Press, 1985), h. 384. 


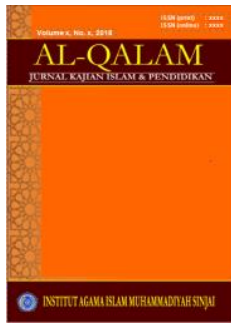

perayaan maulid Nabi, dan hari-hari raya 'id, serta serta bergantian berdoa selama seratus hari kalau raja mangkat. ${ }^{21}$

Ditinjau dari pelaksanaan hukum praktis, proses memutuskan sebuah persoalan kemasyarakatan digunakan dua institusi hukum yaitu hukum sara' dan hukum ade'. Hal ini menunjukkan relasi yang kuat antara kedua paradigma hukum tersebut. Mereka yang menjabat dalam hirarki wewenang institusi parewa sara', memperoleh penghasilan sebagaimana halnya parewa ade'. Penghasilan itu berasal dari hasil sejumlah sawah yang diserahkan untuk dikelolah, sejumlah pungutan atau pemberian, misalnya pada acara pernikahan maupun pada saat memutuskan suatu perkara. Mereka termasuk anggota masyarakat kehormatan, yang sering diundang pada acara-acara keluarga untuk berdoa, mengaji atau membaca Barzanji. ${ }^{22}$

\section{KESIMPULAN}

Sejarah penerimaan Islam di Sulawesi Selatan berimplikasi pada perubahan tatanan sosial politik hubungan antar kerajaan yang eksis saat itu. Penerimaan Islam secara top down; dari penguasa ke rakyat umum, menyebabkan perubahan tatanan pelaksanaan kekuasaan;pemerintahan. Tak terkecuali di Sinjai, implikasi penerimaan Islam penguasa dan rakyat umum, menyebabkan kultur baru dalam tatanan sosial politik, yakni kultur islami dengan berbagai status sosial lembaga atau individu. Status tersebut memiliki fungsi di tengah-tengah masyarakat, yang sifatnya dapat disebut sebagai pelayanan spiritual.

\section{DAFTAR PUSTAKA}

Daeng Patunru, Abd. Razak. Sejarah Gowa (Cet. I; Ujung Pandang: Yayasan Kebudayaan Sulawesi Selatan, 1967).

Daeng Patunru, Abdul Razak dkk, Sejarah Bone (Cet. I; Ujung Pandang: Yayasan Kebudayaan Sulawesi Selatan, 1989).

${ }^{21}$ Ibid.

${ }^{22}$ Cristian Pelras, op. cit., h. 214. 
Daeng Rapi, Ahmad Massiara. Menyingkap Tabir Sejarah Budaya di Sulawesi Selatan (Cet. I; Jakarta: Lembaga Penelitian dan Pelestarian Sejarah dan Budaya Sulawesi Selatan, 1988).

Gising, Basrah. Attoriolongnge ri Bulo-bulo, Tondong, Lamatti-Sejarah Kerajaan Bulo-bulo, Tondong, dan Lamatti (Suatu Bentuk Manifestasi "Sinjai Bersatu”) (Cet. I; Makassar: Era Media, 2002).

Mattulada, Latoa-satu lukisan Analitis Terhadap Antropologi Politik Orang Bugis (Cet. I; Jogyakarta: Gadja Mada University Press, 1985), h. 384.

---------, Sejarah Masyarakat dan Kebudayaan Sulawesi Selatan (Cet. I; Ujung Pandang: Lembaga Penerbitan Universitas Hasanuddin, 1998).

Mustafa, Moh. Yahya dan A. Wanua Tungke, Sinjai 10 Tahun dalam Memori (Cet. I; Makassar: Pustaka refleksi, 2002).

Mustafa, Mustari, Agama dan Bayang-bayang Etis Syaik Yusuf al-Makassari (Cet. I; Makassar: 2011).

Noorduyn, J. De Islamisering van Makassar diterjemahkan oleh S. Gunawan dengan judul Islamisasi Makassar (Cet. I; Jakarta: Bhratara, 1972).

Pelras, Cristian. The Bugis diterjemahkan oleh Abdul Rahman Abu dkk. dengan judul Manusia Bugis (Cet. I; Jakarta: grafika Mardi Yuana, 2006), h. 213.

Salahuddin, Skripsi "Kerajaan Bulo-bulo dalam Persekutuan Tellu Limpoe" (IKIP Ujung Pandang: Fakultas Ilmu Sosial, 1997).

Soekanto, Soejono. Sosiologi-Suatu Pengantar (Cet. 38; Jakarta: Raja Grafindo Persada, 2005). 